\title{
Research on Measures for Development of Nanjing Rail-water Intermodal Transportation based on Development of Hub Economy
}

\author{
Li Zhang \\ Jinling Institute of Technology, Nanjing 211169, China \\ nj.teacher@163.com
}

\begin{abstract}
At present, the proportion of railroad and waterway cargo transportation in China's cargo transportation system is growing year by year, and Rail-water intermodal transportation is highly efficient and less polluting, which is very suitable for the current economic development, and its development has inestimable potential. Facing the growing demand for transportation, it is of special significance to improve the transportation capacity and management level of Rail-water transportation in China. This paper first analyzes the development foundation and environment of Nanjing port, then takes Longtan port as an example and proposes the main measures such as improving Nanjing's Rail-water transportation infrastructure construction, integrating railroad resources, reforming operation and management, and formulating port cluster development planning.
\end{abstract}

Keywords: Hub Economy; Nanjing Rail-water Intermodal Transportation; Port; Measures.

\section{Introduction}

Railway-water intermodal transportation is an efficient way of transporting goods between waterways and railroads, which is important for promoting the construction of comprehensive urban transportation system, improving the modern development of logistics, especially responding to and supporting "the Belt and Road Initiative", "the Yangtze River Economic Belt" and other national strategies. The powerful advantages and roles of Nanjing as a national transportation hub city and a national transportation hub city are increasingly apparent. Nanjing as a national comprehensive transportation hub city and the Yangtze River Delta mega-city, Rail-water intermodal transportation has a unique advantage that is difficult to reach other cities along the river, especially after the 12.5meter deep-water channel to Nanjing, Nanjing will realize a huge leap and transformation from "riverrail" to "sea-rail". This paper will explore the current situation and problems of Nanjing's Rail-water intermodal transportation, analyze the relevant foundation and environment, and propose measures for Nanjing's Rail-water intermodal transportation development based on the hub economy, taking Longtan Port as an example.

\section{Current Status of Nanjing Rail-water Intermodal Transportation Development}

Nanjing Port is one of the 25 main hub ports along the coast of China and one of the first-class ports open to the public, located at the combination of the Yangtze River and the eastern coastal "T" economic development strategy belt, with the location advantage of connecting the east and west and the north and south. Nanjing Port has five modes of transportation, connecting the Yangtze River basin and more than 10 provinces and cities in the Central China, East China, South China and North China, radiating nearly 200 ports in more than 80 countries and regions. With the extension of the 12.5-meter deep water channel to Nanjing, Nanjing Port has become the most inland international deep water seaport, the most direct and quickest sea port in the middle and upper reaches of the Yangtze River, and the comprehensive hub port of river-sea transshipment linking China to the world. 


\subsection{Current Status of Nanjing Container Railroad Transportation}

At present, container transportation is a new type of transportation product implemented by Chinese railroad to meet the market development needs, which can enhance the market competitiveness, open up market share, and is mandatory to achieve good railroad development. The perfect railroad infrastructure conditions for Nanjing Port provide a good hardware foundation for the development of Nanjing's Rail-water intermodal transportation. Nanjing Port currently has three Rail-water intermodal transportation areas, namely, Xinshengwei, Xiba and Pukou, with a total of 40,050 meters of dedicated rail lines, 25 loading and unloading lines, and an annual throughput capacity of about 29 million tons.

\subsection{Currently Status of Nanjing Container Water Transportation}

At present, Nanjing has formed "one ring, two spans and eight lines" of the mega railroad hub pattern [1], and undertakes the arrival and departure marshaling of Yangtze River Delta region railway lines and stations. Nanjing has $28 \%$ of the provincial Yangtze River mainline resources, and the port throughput is increasing year by year. Nanjing Port is one of the most upstream ports in the Yangtze River for large vessels of 50,000 tons, and it is facing great opportunities in terms of economic development and long-term trend of institutional reform. Thus, Nanjing Port has an excellent strategic position in the country and is bound to become the focus for national logistics development.

\subsection{Current Status of Nanjing Container Rail-water Intermodal Transportation}

Nanjing Port is the only port in the middle and lower reaches of Yangtze River that seamlessly connects container railroad and waterway, and in 2020 Nanjing Port achieved a port throughput of 251.99 million tons, ranking the first inland river port in China, and a container of 3.02 million TEU, ranking the second inland river port in China. In the first half of 2021, Nanjing Port completed a cargo throughput of 139.99 million tons, up $19.4 \%$ year-on-year, and the container throughput reached 1.525 million TEU, up $6.64 \%$ year-on-year.

\section{Problems of Nanjing Container Rail-water Intermodal Transportation}

\subsection{Poor Connection of Transportation Organizations}

At present, there is no coordination between Nanjing Port itself and upstream and downstream ports. Technology, equipment and facilities do not match, such as inconsistent loading and unloading equipment, inconsistent layout and parameters of port facilities. Container loading and unloading stations are not coordinated with ports and other transportation hubs, the layout is unreasonable, and the number of inland refueling stations is insufficient. Some container port handling technologies can no longer meet the needs of market development.

\subsection{Low Level of Information Sharing of Rail-water Intermodal Transportation}

The information platform of Rail-water intermodal transportation in Nanjing Port has been initially built, but the level of information sharing needs to be improved. The business information from port and shipping enterprises is relatively transparent to users, while the business information from railroad departments is less transparent. The information interaction between various nodes of Railwater intermodal transportation, such as ports, railroad companies and cargo owners, is poor in timeliness. Nanjing Port and port management information systems around the world are not unified and the technological level varies. Information from all parties cannot be shared in real time, which greatly restricts the development of Rail-water intermodal transportation [2].

\subsection{The Level of Port Operation and Management Needs to be Improved}

Although the Ministry of Railways was divided into Railway Bureau and China Railway Corporation after the reform of the ministerial system and the separation of government and 
enterprises, it still failed to unify the management of railroad and water transportation, resulting in the long-term separation of railroad and water transportation, and the problem of coordination of railway-water intermodal transportation is prominent. Nanjing's unique port distribution characteristics and differentiated operation and management modes have led to the lack of a unified and authoritative coordinating agency or operating body for the various departments involved in Railwater intermodal transportation to formulate development strategies and policies for Rail-water intermodal transportation, which also reduces the level of operation and management of port railroads and weakens the core competitiveness of Nanjing's Rail-water intermodal transportation.

\section{Advantages and Forecast of Nanjing Rail-water Intermodal Transportation}

\subsection{Advantages of Nanjing Rail-water Intermodal Transportation}

(1) Advantages of Comprehensive Transportation Hub

Nanjing is one of the 42 comprehensive transportation hubs in China and has basically established a comprehensive transportation system with seaports, airports and dry ports as hubs and railroads, highways, waterways, airlines and pipelines as interconnections. With the completion and operation of a large number of high-standard modern railroads such as Beijing-Shanghai high-speed railway, Shanghai-Nanjing intercity railway, Ning-Hang high-speed railway and other large comprehensive hub stations such as Nanjing South Station, Nanjing has developed into the largest railroad hub in East China. The rapid development of railroads and ports has laid a solid foundation for the development of Rail-water transportation in Nanjing.

(2) Relatively Perfect Port Railroad Infrastructure

Comparing the environment and conditions of Rail-water intermodal transportation between Nanjing Port and the four downstream ports of Yangtze River, the four downstream ports are still in the initial stage of Rail-water intermodal transportation or infrastructure construction, while the port areas of Pukou, Xinshengwei and Xiba of Nanjing Port have been carrying out Rail-water intermodal transportation for many years, so Nanjing Port has an absolute advantage in terms of scale and experience.

(3) Outstanding Advantages of Railroad Transportation Resources

Nanjing East Railway Station has been designated as one of the two major marshaling stations of Shanghai Railway Bureau, which is responsible for the arrival and departure of vehicles from various railway lines and stations in the Yangtze River Delta region, and Nanjing Port has been cooperating with Nanjing East Railway Station for many years to carry out intermodal transportation by rail and water. In addition, Pukou Area of Nanjing Port is a railroad coal launching port, which brings ample emptying vehicles to Nanjing Port. The above-mentioned structural characteristics of cargo source give Nanjing Port the advantage of Rail-water intermodal transportation resources.

\subsection{Forecast on Development of Nanjing Rail-water Intermodal Transportation}

According to the Master Plan of Nanjing Port and considering the impact of the 12.5-meter deep water channel navigating through to Nanjing and the construction of Jiangbei National New Area, Nanjing Port as a node of river-sea transshipment, will see a substantial increase in cargo throughput. Considering the competition from downstream ports such as Taicang Port, it is predicted that the cargo throughput of Nanjing Port will reach 380 million tons in 2030 and 440 million tons in 2040 [3].

Combined with the above analysis of the Rail-water intermodal cargo volume, it is expected that in the long term, with the construction and operation of railroad lines in the port areas of Qiba and Tongjing and the improvement of facilities such as the Longtan and Xiba port area harbor-diversion railroads, the Rail-water intermodal cargo volume of Nanjing will see a large increase in 2030, and the proportion of Rail-water intermodal transportation will exceed 10\% [3]. The forecast of Railwater intermodal freight volume in Nanjing Port is shown in the table below. 
Table 1. Forecast of Rail-water Intermodal Traffic in Nanjing Port (Unit: 10,000 tons)

\begin{tabular}{|c|c|c|c|c|c|c|c|}
\hline \multirow{4}{*}{$\mathbf{4}$} & Coal & 850 & 30 & 290 & 150 & 10 & 1330 \\
\cline { 2 - 7 } & Metal Ores & 80 & 80 & 110 & & & 270 \\
\cline { 2 - 7 } & Steel & & 10 & & 100 & 420 & 530 \\
\cline { 2 - 7 } & Product Oil & 25 & 20 & & & & 45 \\
\cline { 2 - 7 } & $\begin{array}{c}\text { Container (10,000 } \\
\text { TEU) }\end{array}$ & 38 & & 80 & 20 & & 138 \\
\cline { 2 - 7 } & Others & 196 & 40 & 250 & & 35 & 521 \\
\cline { 2 - 7 } & Total & 1455 & 180 & 1290 & 410 & 465 & 3800 \\
\hline
\end{tabular}

\section{Example Analysis of Nanjing Rail-water Intermodal Transportation based on Development of Hub Economy}

Longtan Port Area is the most important container port in Nanjing, a large comprehensive deep water port area and an important national railroad container distribution center in the future. It is the main support for Nanjing to build the Yangtze River shipping and logistics center, with broad development prospect and prominent strategic position, which puts forward higher requirements for the collection and distribution system in the port area. Longtan Port Area is adjacent to the largest freight consolidation station in East China - Yaohuamen Railway, the upcoming Beijing-Shanghai Railway Longtan Container Handling Station and Longtan Highway Freight Station. With the construction of 12.5-meter deep canal of Yangtze River, Longtan Deep Water Port Area is constantly improved, effectively realize the construction layout upgrade and optimization, and enhance the space, enabling 100,000 tons of ocean-going vessels to enter the port with the tide.

\subsection{Longtan Port Operation Process}

As the largest hub in East China, Nanjing has resources at its fingertips, mainly including container area, heavy and miscellaneous cargo area and special express area. At present, the comprehensive logistics hub of Nanjing Port Longtan Port Area is selected as a port-type (production service type) national logistics hub. Nanjing Port (Production Service) National Logistics Hub consists of bonded logistics area, port logistics area, supply chain logistics area, public-Rail-water intermodal area and comprehensive business area, covering an area of about 11.84 square kilometers. Among them, the public-Rail-water intermodal area relies on Longtan port railroad line, Longtan container handling station, Nanjing East Station grouping station, Yaohuamen railroad yard, etc. to build a comprehensive railroad container logistics center and public-Rail-water intermodal center.

\subsection{Rail-water Intermodal Transportation Cargo}

For bulk cargoes such as coal and metal ores suitable for railroad transportation, the construction of railroad special line in Longtan Port Area will leverage the characteristics of low comprehensive railroad medium and long-distance transportation price, large transportation capacity, low environmental impact and low influence by climate, etc. It will play an important supplementary role for port container transportation and coal and metal ores collection and distribution, effectively promoting the development of the port area.

\subsection{Analysis of Development Trend}

According to Preliminary Design of Longtan Port Area Railway Special Line, the predicted traffic volume of Longtan Railway Special Line in 2025 and 2035 is as follows [3]. 
Table 2. Forecast on Cargo Arrival and Departure on Longtan Railroad Special Line (Unit: 10,000 tons)

\begin{tabular}{|c|c|c|c|c|c|c|}
\hline \multirow{2}{*}{ Goods Type/Year } & \multicolumn{3}{|c|}{$\mathbf{2 0 2 5}$} & \multicolumn{3}{c|}{$\mathbf{2 0 3 5}$} \\
\cline { 2 - 6 } & Deliver & Arrival & Total & Deliver & Arrival & Total \\
\hline Coal & 200 & 0 & 200 & 340 & 0 & 340 \\
\hline Metal Ores 860 & 80 & 0 & 80 & 140 & 0 & 140 \\
\hline Container Weight & 20 & 190 & 210 & 70 & 310 & 380 \\
\hline Container Volume (10,000 TEU) & 3 & 22 & 25 & 10 & 36 & 46 \\
\hline Total & 300 & 190 & 490 & 550 & 310 & 860 \\
\hline
\end{tabular}

\subsection{Opportunities and Challenges}

\subsubsection{Opportunities}

(1) Large demand for container transportation. At present, the annual container transportation volume of Longtan Port is close to 3 million TEU. According to the preliminary estimation, after the completion of the port-dredging railroad, about $20 \%$ of the container transit volume of public water can be transformed into Rail-water intermodal transportation volume.

(2) It has good external railroad connection conditions. Longtan port railroad is connected to railroad Beijing-Shanghai line, relying on Nanjing mega railroad hub, the port area has great advantages in carrying out Rail-water intermodal transportation. Through the sea-rail transit in Longtan port and connecting with Ning-Xin-Europe channel, the near and distant ocean cargo can be conveniently connected with the central and western regions of China as well as Central Asia, West Asia and Europe, which can play a great advantage in expanding the foreign trade in the central and western regions and "the Belt and Road Initiative".

\subsubsection{Challenges}

The target market of Longtan Port for container Rail-water intermodal transportation is mainly located in the major cities in central and western China. In the face of many major coastal ports which have already started container Rail-water intermodal transportation and have first-mover advantages, there will be more fierce competition.

\section{Nanjing Rail-water Intermodal Transportation Development Strategy based on Development of Hub Economy}

\subsection{Improve Infrastructure Construction of Nanjing Rail-water Intermodal Transportation}

The construction of a special rail line in the port area is a very important part of the Rail-water intermodal transportation infrastructure, which can not only expand the radiation range of container Rail-water intermodal transportation, but also realize the joint transportation of "water-rail" mode, and thus realize the "seamless connection" between railroad and water transportation [4]. According to the overall planning of Nanjing city and the general plan of railroad hub and considering the construction of ports and logistics parks in Nanjing, the Longtan container handling station is planned to be built in Longtan Port of Beijing-Shanghai Railroad, and the railroad arrival and departure line, operation line and supporting facilities are built according to the effective length of 1,050 meters.

\subsection{Integration of Railroad Resources}

The port and the railroad should integrate the resources related to the port railroad through consultation, so as to avoid the decrease of transportation efficiency caused by multi-segment transportation management and frequent over-track transportation; the resources can be integrated to fully exploit the transportation capacity of the terminal branch line and enhance the scale benefit. It is proposed to set up a railroad construction and operation management platform at Nanjing municipal level to integrate the existing dedicated railroad and railroad line resources in Nanjing. The municipal government authorizes corporate bodies with transportation infrastructure investment, construction 
and operation functions to take the lead in creating a railroad management platform, tapping the capacity of existing railway lines, exploring the market-oriented development of dedicated railroad lines, and realizing the cooperation of the city's railroad resources in terms of information and market resources.

\subsection{Reform on Operation Management}

Conflicts of interest in single-party independent operation of Rail-water intermodal transportation are not conducive to sustainable development. The new joint venture companies may cause a waste of resources, so it is recommended that China Yangtze Shipping Investment Group to take main responsibilities for the operation of Rail-water intermodal transportation. China Yangtze Shipping Investment Group integrates the provincial and municipal state-owned assets, and develops with Nanjing Yangtze River shipping and logistics. It serves as a good platform in building a convenient port collection and distribution system and realizing the benefit sharing of all social parties. It can absorb Nanjing Port, Shanghai Railway Bureau and other logistics entities through equity adjustment to realize multi-participation and win-win benefit.

\subsection{Plan Port Cluster Development}

Using the natural attributes of port clusters and economic laws to coordinate development, and combining with national strategies such as "the Belt and Road Initiative", Nanjing Port will further enhance its hub status, build an important node of the container transportation system in the Yangtze River Basin and an important part of Shanghai International Shipping Center, and further enhance Nanjing Port's function of serving the Yangtze River Delta and radiating the middle and upper reaches. Nanjing Port will further develop its own advantages, strengthen the docking with the provincial port group and the synergy with the development of ports along the Yangtze River, vigorously develop new shipping industries and new economy, formulate the development plan of the port cluster, adopt the form of complementary scale with the hinterland, and promote the coordinated development of the port as a whole.

\section{Acknowledgments}

[Funded Project] This paper is the result of the project of the Humanities and Social Sciences Research Planning Fund of the Ministry of Education of China, "Research on the Optimization of Logistics System and Transformation and Upgrading in the Context of 'the Belt and Road Initiative"” (17YJA790027).

\section{References}

[1] Peng Lv, Zhimin Zhu. "Research on Development Strategy of Container Rail-water Intermodal Transportation in Nanjing Longtan Port" [J]. Port Economics. 2017, 5: pp. 15-19.

[2] Changyu Liu. "Study on Development Status of Rail-water Intermodal Transportation in Hubei Province and Its Measures" [J]. Shanxi Construction. 2019, 6: pp. 162-163.

[3] "Analysis and Practical Research on Nanjing Rail-water Intermodal Transportation and Port Rail System in Context of Developing Hub Economy" [R]. Nanjing Transportation Group. 2016. 12.

[4] Yanyi Chen, Hongyu Dong, Jianan Zhang, Ying Cao. "Current Status and Measures for the Development of Rail-water Intermodal Transportation in Yangtze River Mainline Ports" [J]. Research and Discussion. 2019, 2: pp. 11-15. 